\title{
Garut Flash Flood Victim's Families: Relation Between Stress Management and Family Resilience Based on Residence and Post-disaster Time
}

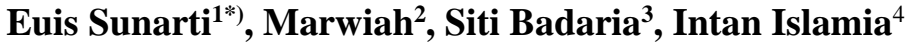 \\ 1,2,3 Department of Family and Consumer Sciences, Faculty of Human Ecology, IPB University, \\ Bogor 16680, West Java, Indonesia \\ ${ }^{4}$ Department of Islamic Psychology, Raden Intan State Islamic University of Lampung. 35131 \\ Bandar Lampung \\ *) Corresponding author: euissunarti@apps.ipb.ac.id
}

\begin{abstract}
This research aimed to analyze stress management (stressors, coping strategies, and stress symptoms) and family resilience (process and output) of garut flash flood victim families at 1 and 4 months post-disaster. This cross-sectional study involved 120 families (each 60 from the temporary shelter (FTS) and nontemporary shelter (FNTS)) who were chosen by stratified non-proportional random sampling. The results showed that FNTS faced higher stressors and did higher coping strategies than FTS, either at 1 or 4 months post-disaster. Stress symptoms were also higher among FNTS at 1-month post-disaster, while the output of family resilience was higher in FTS at 4 months post-disaster. Stressors significantly influenced stress symptoms at 1-month post-disaster, coping strategies and the process of family resilience. In contrast, stressors influenced stress symptoms at 4 months post-disaster, coping strategies and stress symptoms 1-month post-disaster. The process of family resilience influenced the output of family resilience at 1-month post-disaster. In contrast, the output of family resilience at 4 month post-disaster was influenced by residence, family income per capita, stressors and the process of family resilience. This study reinforces the importance of family resilience in disaster-prone areas.
\end{abstract}

Keywords: disaster risk, family resilience, post-disaster investment, temporary shelter

\begin{abstract}
Abstrak
Penelitian ini bertujuan untuk menganalisis manajemen stres (stresor, strategi koping, dan gejala stres) dan ketahanan keluarga (proses dan output) keluarga korban banjir bandang garut yang tinggal di shelter sementara dan nontemporer pada 1 dan 4 bulan pasca bencana. Studi potong lintang ini melibatkan 120 keluarga (masing-masing 60 di penampungan sementara (KPS) dan rumah asalnya (KRA)) yang dipilih secara stratified nonproportional random sampling. Hasil penelitian menunjukkan bahwa KRA menghadapi stresor yang lebih tinggi dan melakukan strategi coping yang lebih tinggi dibandingkan KPS, baik pada 1 atau 4 bulan pasca bencana. Gejala stres juga lebih tinggi pada KPS pada 1 bulan pasca bencana sedangkan output ketahanan keluarga lebih tinggi pada KRA pada 4 bulan pasca bencana. Gejala stres pada 1 bulan pasca bencana dipengaruhi secara signifikan oleh stresor, strategi koping dan proses ketahanan keluarga, sedangkan gejala stres pada 4 bulan pasca bencana dipengaruhi oleh stresor, strategi koping dan gejala stres 1 bulan pasca bencana. Output ketahanan keluarga pada 1 bulan pasca bencana dipengaruhi oleh proses ketahanan keluarga sedangkan output ketahanan keluarga pada 4 bulan pasca bencana dipengaruhi oleh tempat
\end{abstract}


tinggal, pendapatan per kapita keluarga, stresor dan proses ketahanan keluarga. Penelitian ini menguatkan pentingnya resiliensi keluarga di wilayah rawan bencana.

Kata kunci: hunian sementara, investasi pascabencana, resiliensi keluarga, risiko bencana

\section{Introduction}

Geographical conditions and degradation of the natural environment make Indonesia a very disaster-prone country. In 2016, the number of disasters in Indonesia reached the highest number in the last 15 years (BNPB, 2016). There were 2.369 disasters happened and 90 percent of them are hydro-meteorological disasters Garut flash flood that occurred in September is one of the biggest hydro-meteorological disasters in 2016 that caused 830 houses heavily damaged, 473 houses moderately damaged and 1.226 houses lightly damaged. In addition, the flood has also caused 34 casualties, 19 missing persons, 9 injured and 787 displaced families (BPBD, 2016). Severe disasters can lead to serious disruption, trauma and loss for families (Walsh, 2007). Many families who lost their homes due to the Garut flash flood are displaced to temporary shelters provided by the government. However, due to the limited capacity of temporary shelters, many families stayed in their original residence (nontemporary shelter). According to McCubbin and Thompson (1997), families in temporary and nontemporary shelters both face multiple changes that can turn to be stressors. The stressor is changed that disrupts family life. The family needs to have a good stress management. Unmanaged stressors can cause stress symptoms among family members, and it can be malaise symptoms which is signs of physical stress or mood symptoms which is signs of psychological stress (Mirowski \& Cathrine, 2002). Factors that affect stress symptoms are stressors, family appraisal, family resources, and coping strategies (Walsh, 2007) and coping is a cognitive and behavioural process to reduce the stress that comes in the face of stressful situations (Rubbiyana, 2012).

Many families apply stress management in daily life, but in severe stress conditions or even experiencing a crisis (such as becoming a disaster victim), family needs to have resilience (MacPhee, Lunkenheimer, \& Riggs, 2015; Sunarti, 2015), it is the ability to survive and return to the original state in the event of misfortune (Walsh, 2002; Sunarti, 2007). According to Walsh (2003), it formulates a key process of family resilience, several qualities that can help the family cope with severe stressors during crisis situations. The key process of family resilience consists of three components: family belief system, organizational pattern, and communication process (Walsh, 2002; Walsh, 2003). Family belief system includes making meaning of adversity, positive outlook, transcendence and spirituality; organizational patterns include flexibility, connectedness, social and economic resources; communication process includes clarity, open emotional expression, and problem-solving collaboration (Walsh, 2002; Walsh, 2003). There are two different common views in the theory of resilience. Some theorists and researchers think that family resilience can be better understood as a process, but others revealed that resilience could be conceptualized as capabilities or output (Oh \& Chang, 2014). Therefore, this study tried to distinguish between resilience as a process and resilience as an output. The output of family resilience is formed from the interaction between risk factors and protective factors. Risk 
factors are an occurrence or condition that potentially leads the family to have negative adaptation outcomes, while protective factors are resources that can facilitate the family to have positive adaptation outcomes (Benzies \& Mychasiuk, 2009). Previous research commonly used the key process of family resilience formulated by Walsh (2003) to measure the output of family resilience. The key process of family resilience is part of protective factors (Benzies \& Mychasiuk, 2009), so those studies have not accurately measured the output of family resilience. Therefore, this study developed a new instrument to measure the output of family resilience. The quality of output of family resilience can be demonstrated by the family's ability to decide, solve the problem, adapt, anticipate, access support and recover (Sunarti, 2007).

Resilience is unique to each different context of adversity, and family may be resilient with certain stressors but fail with other stressors (McDermott \& Cobham, 2012; Benzies \& Mychasiuk, 2009). There is still limited research about family resilience in the context of natural disasters, especially flash floods. Previous research about resilience in disaster context mostly focus on individual, especially children. Resilience is also dynamic over time because risk factors and protective factors are non-static(Oh \& Chang, 2014; Patterson, 2002). So it is necessary to capture family resilience as well as family stress management at several points in time. McDermott and Cobham (2012) found the frequency of family dysfunction is higher in the early post-disaster. The early post-disaster period is a crisis period, so it is interesting to study the condition of Garut flash flood victim families at 1 and 4 months post-disaster. Not only in terms of time, but the residence also can affect family's stress level and resilience. Victims of Hurricane Katrina who returned to their homes had better resilience than displaced victims (Glandon, Muller, \& Almedom, 2008). In contrast, people who remained in their former region after the earthquake in Armenia were more prone to psychological problems than those who relocated (Najarian, Majeed, \& Gasparyan, 2017). Therefore, families in temporary and nontemporary shelters are expected to have different stress management as well as output of family resilience.

Based on those problems, this study aimed to analyze: 1) the difference of family characteristics, stressors, coping strategies, stress symptoms, processes and output of family resilience of Garut flash flood victim families at 1 and 4 months post-disaster; 2) the influence of family characteristics, stressors, coping strategies, and process of family resilience toward family stress symptoms and output of family resilience among Garut flash flood victim families at 1 and 4 months post-disaster.

\section{Participants}

\section{Methods}

The design of this study was a cross-sectional and retrospective study. It was involved 120 victim families of Garut flash flood selected by non-proportional stratified random sampling from those living in a temporary and nontemporary shelter (every 60 families). Tarogong Kidul sub-district was chosen purposively because it was the subdistrict with the worst damage in the housing sector which as many as 1.302 houses were damaged from a total of 2.529 houses affected by flash flood (BPBD, 2016). The location of temporary shelter i.e. Transito, LPSE, LEC, Islamic Center, Gandasari, and AlMusadaddiah, was chosen purposively considering that there were victim families from 
Tarogong Kidul Sub-district in those shelters. Meanwhile, nontemporary shelter location was chosen purposively in RW 10 (RT 3 and RT 4) and RW 19 (RT 3 and RT 4) because it is located right on the edge of Cimanuk river flow and suffered the worst impact. Data of this research were collected during February 2017.

\section{Measurement}

Data were collected through a survey with wife as the respondent using a structured questionnaire, which included: (1) family characteristics (husband's age, wife's age, length of husband's education, length of wife's education, family size, and family income per capita before the disaster, 1 and 4 months post-disaster); (2) stressors (intra-family strains, marital strains, financial strains, work strains, housing strain, and loss, illness-family care) ; (3) coping strategies (problem-focused and emotional focused); (4) stress symptoms (malaise, mood); (5) process of family resilience (belief system, organizational pattern, communication process), and (6) output of family resilience (decision-making, problemsolving, adaptation, financial security, social support access, anticipation, recovery). Stressors were measured using a modified questionnaire from Family Inventory Life and Change (FILE) by McCubbin and Thompson (1981) with Cronbach's alpha 0.611. Coping strategies were measured using a modified questionnaire from Lazarus and Folkman (1985) with Cronbach's alpha 0.688. Stress symptom was measured using a modified questionnaire from Mirowsky and Ross (2002) with Cronbach's alpha 0.821.

The process of family resilience was measured using a modified questionnaire from Sunarti, Praptiwi, and Muflikhati (2011) based on the key process of family resilience by Walsh (2003) with Cronbach's alpha 0.868. The output of family resilience was measured using a self-developed questionnaire based on the construct of family resilience indicator by Sunarti (2007) with Cronbach's alpha 0.823. The questionnaires of stressors, coping strategies, stress symptoms, and process of family resilience provided two choices of answers (yes and no with scores 0 and 1), while the output of the family resilience questionnaire used a rating scale 1-7. The higher the score, the higher the stressors, coping strategies, stress symptoms, the process of family resilience, and output of family resilience.

\section{Analysis}

Obtained score from each main variable was transformed into an index score for further analysis. The data analysis consisted of descriptive (maximum, minimum and mean scores) and inferential analysis (T-Test and multiple linear regression tests) using Microsoft Excel for Windows and Statistical Package for The Social Science (SPSS 16). Paired TTest was conducted to analyze the difference between family characteristics, stressors, coping strategies, stress symptoms, process and output of family resilience of Garut flash flood victim families at 1 and 4 months post-disaster. Multiple linear regression analysis was conducted to analyze factors affecting stress symptoms and output of family resilience. The classic assumption test showed that the data normally spread (its skewness and kurtosis ratio were between -2 and +2 ) and was free from heteroscedasticity. However, there was multicollinearity between the husband's age and the wife's age, so the husband's age was not included in the regression model. 


\section{Findings}

\section{Family Characteristics}

The minimum, maximum and mean scores of family characteristics are presented in Table 1. The average of families in this research were medium-sized families (5-7 members). Both husbands and wives, on average, were categorized as middle age (around 40 years), and the average of education was only equivalent to primary school or has not fulfilled the 12-year compulsory education. The average family income per capita at 4 months post-disaster (IDR 467.000) was higher than the average family income per capita at1 month post-disaster (IDR 239.000) but still lower than the average of family income per capita at pre-disaster (IDR 692.000).

Table 1. Minimum, maximum and mean score of family characteristics

\begin{tabular}{|c|c|c|c|}
\hline Characteristics (unit) & $\begin{array}{c}\text { FTS } \\
\text { (Min- Max; Mean) }\end{array}$ & $\begin{array}{c}\text { FNTS } \\
\text { (Min- Max; Mean) }\end{array}$ & $\begin{array}{c}\text { Total } \\
\text { (Min- Max; Mean) }\end{array}$ \\
\hline Age of husband (year) & $28.0-85.0 ; 43.3$ & $22.0-71.0 ; 46.0$ & $22.0-85.0 ; 44.5$ \\
\hline Age of wife (year) & $23.0-68.0 ; 39.1$ & $21.0-70.0 ; 41.3$ & $21.0-70.0 ; 41.0$ \\
\hline $\begin{array}{l}\text { Length of husband's } \\
\text { education (year) }\end{array}$ & $4.0-12.0 ; 7.55$ & $4.0-22.0 ; 8.1$ & $2.0-2.0 ; 4.5$ \\
\hline $\begin{array}{l}\text { Length of wife's education } \\
\text { (year) }\end{array}$ & $4.0-13.0 ; 7.38$ & $2.0-15.0 ; 7.6$ & $4.0-22.0 ; 7.8$ \\
\hline Family size (person) & $2.0-8.0 ; 4.0$ & $2.0-12.0 ; 4.0$ & $2.0-15.0 ; 7.0$ \\
\hline $\begin{array}{l}\text { Family income/cap/month } \\
\text { before disaster (IDR } \\
\text { thousand) }\end{array}$ & $28.5-3300.0 ; 676.0$ & $42.0-3571.0 ; 763.0$ & $28.5-571.0 ; 692.0$ \\
\hline $\begin{array}{l}\text { Family income/cap/month at } 1 \\
\text { month post-disaster (IDR } \\
\text { thousand) }\end{array}$ & $0.0-625.0 ; 366.0$ & $0.0-1000.0 ; 112.0$ & $0.0-1625.0 ; 239.0$ \\
\hline $\begin{array}{l}\text { Family income/cap/month at } 4 \\
\text { months post-disaster (IDR } \\
\text { thousand) }\end{array}$ & $0.0-1625.0 ; 354.0$ & $0.0-2857.0 ; 578.0$ & $0.0-2857.0 ; 467.0$ \\
\hline
\end{tabular}

\section{Stressors}

Mean scores and the T-test results between stressors at 1 and 4 months post-disaster are presented in Table 2. Based on mean scores, the result showed stressors experienced by families in the nontemporary shelter was significantly higher than families in a temporary shelter at 1 and 4 months post-disaster. The number of stressors tended to decrease at 4 month post-disaster, both in families in temporary and nontemporary shelter. Housing strain was the most experienced stressors by families, both in the temporary and nontemporary shelter at 1 and 4 months post-disaster.

Table 2. Mean scores and result of T-test between stressors at 1 and 4 month post-disaster

\begin{tabular}{|c|c|c|c|c|c|c|}
\hline \multirow[t]{2}{*}{ Stressors } & \multicolumn{2}{|c|}{1 month } & \multirow[t]{2}{*}{$P$-value } & \multicolumn{2}{|c|}{4 months } & \multirow[t]{2}{*}{$P$-value } \\
\hline & FTS & FNTS & & FTS & FNTS & \\
\hline Intra-family strain & 33.0 & 41.3 & $0.013^{* * *}$ & 18.0 & 14 & 0.232 \\
\hline Marital strains & 18.9 & 39.1 & $0.000^{* * *}$ & 17.2 & 18.2 & 0.901 \\
\hline Financial strains & 7.4 & 22.7 & $0.000^{* * *}$ & 6.7 & 21.1 & $0.000^{* * * *}$ \\
\hline Work strains & 35.0 & 33 & 0.578 & 22.8 & 30.8 & $0.047^{* *}$ \\
\hline
\end{tabular}


Table 2. Mean scores and result of T-test between stressors at 1 and 4 month post-disaster (Cont..)

\begin{tabular}{|c|c|c|c|c|c|c|}
\hline \multirow{2}{*}{ Stressors } & \multicolumn{2}{|c|}{1 month } & \multirow[t]{2}{*}{$P$-value } & \multicolumn{2}{|c|}{4 months } & \multirow[t]{2}{*}{$P$-value } \\
\hline & FTS & FNTS & & FTS & FNTS & \\
\hline Housing strain & 63.9 & 66.6 & 0.285 & 65 & 61.7 & 0.541 \\
\hline Loss, ilness \& family care & 4.3 & 9 & 0.450 & 2 & 3.7 & 0.151 \\
\hline Total & 22.8 & 31.6 & $0.00^{* * * *}$ & 17.8 & 21.6 & $0.025^{* *}$ \\
\hline
\end{tabular}

\section{Coping Strategies}

Mean scores and the T-test results between coping strategies at 1 and 4 months postdisaster are presented in Table 3. The average score of coping strategies in total was higher among families in the nontemporary shelter (compared to temporary shelter), especially in 1 month post-disaster (compared to 4 months post-disaster). These results indicate that coping strategies were applied more by families in nontemporary shelters and used more at 1 month post-disaster. The results also showed that both families in the temporary and nontemporary shelter did more emotional focus strategies in 1 month or 4 months postdisaster.

Table 3. Mean scores and the result of t-test between coping strategies in 1 and 4 months post-disaster

\begin{tabular}{|c|c|c|c|c|c|c|}
\hline \multirow[t]{2}{*}{ Coping Strategies } & \multicolumn{2}{|c|}{1 month } & \multirow[t]{2}{*}{$P$-value } & \multicolumn{2}{|c|}{4 months } & \multirow{2}{*}{$\begin{array}{c}P- \\
\text { value }\end{array}$} \\
\hline & FTS & FNTS & & FTS & FNTS & \\
\hline Problem focused & 49.4 & 54.4 & 0.132 & 43.8 & 48.2 & 0.470 \\
\hline Emotion focused & 69.9 & 72.9 & $0.000^{* * *}$ & 64.2 & 67.6 & 0.137 \\
\hline Total & 59.7 & 63.7 & $0.000^{* * * *}$ & 54.0 & 57.9 & 0.808 \\
\hline
\end{tabular}

\section{Stress Symptoms}

Mean scores and the results of the T-test between stress symptoms at 1 and 4 months post-disaster are presented in Table 4 . Based on the region, the average stress symptoms (malaise, mood, total) in the nontemporary shelter were higher than families in temporary shelter. Meanwhile, based on the time, families in temporary and nontemporary shelters experienced more stress symptoms in 1 month post-disaster than in 4 months post-disaster.

Table 4. Mean scores and result of T-test between stress symptoms in 1 and 4 months postdisaster

\begin{tabular}{|c|c|c|c|c|c|c|}
\hline \multirow[t]{2}{*}{ Stress Symptom } & \multicolumn{2}{|c|}{1 month } & \multirow[t]{2}{*}{$P$-value } & \multicolumn{2}{|c|}{4 months } & \multirow[t]{2}{*}{$P$-value } \\
\hline & FTS & FNTS & & FTS & FNTS & \\
\hline Malaise & 31.9 & 43.7 & $0.000^{* * * *}$ & 11.8 & 13.7 & 0.504 \\
\hline Mood & 36.5 & 46.5 & $0.000^{* * * *}$ & 16.3 & 31.0 & $0.000^{* * *}$ \\
\hline Total & 33.9 & 44.9 & $0.000^{* * * *}$ & 13.8 & 21.2 & $0.005^{* * * *}$ \\
\hline
\end{tabular}

Note. $* * *$ significant at $\mathrm{p}<0.01$ 
The family experienced stress symptoms consisting of malaise and mood. Stress symptoms malaise indicated by such discomfort, fatigue, and hard to concentrate. Meanwhile, several stress symptoms of mood experienced by family indicated by worry, anxiety, eating and sleeping disorder, feeling irritated, and sad.

\section{Process of Family Resilience}

Mean scores and the T-test results between the process of family resilience at 1 and 4 months post-disaster are presented in Table 5. From all the indicators, only flexibility (among families in nontemporary shelter at 1-month post-disaster) had low achievement $(<66.7)$, but the other indicators mostly showed good achievement. Family in the temporary shelter had the better meaning of adversity; transcendence and spirituality; connectedness; social and economic resources; and organizational pattern either at 1 or 4 months post-disaster. Based on times, the process of family resilience was higher at 4 months post-disaster compared to 1-month post-disaster in both residences.

Table 5. Mean scores and the result of t-test between the process of family resilience in 1 and 4 months post-disaster

\begin{tabular}{|c|c|c|c|c|c|c|}
\hline \multirow{2}{*}{$\begin{array}{l}\text { Process of } \\
\text { family resilience }\end{array}$} & \multicolumn{2}{|c|}{1 month } & \multirow[b]{2}{*}{$p$-value } & \multicolumn{2}{|c|}{4 months } & \multirow[b]{2}{*}{$p$-value } \\
\hline & FTS & FNTS & & FTS & FNTS & \\
\hline $\begin{array}{l}\text { Making meaning } \\
\text { of adversity }\end{array}$ & 100.0 & 76.7 & $0.000^{* * *}$ & 100.0 & 94.2 & $0.006^{* * *}$ \\
\hline Positif outlook & 90.0 & 84.0 & $0.092^{* *}$ & 91.3 & 90.3 & 0.771 \\
\hline $\begin{array}{l}\text { Transcendence } \\
\& \text { spirituality }\end{array}$ & 79.7 & 93.3 & $0.000^{* * *}$ & 79.7 & 94.0 & $0.000^{* * *}$ \\
\hline Belief system & 87.4 & 86.1 & 0.704 & 87.9 & 92.5 & $0.043^{* *}$ \\
\hline Flexibility & 68.3 & 54.2 & $0.027^{* *}$ & 82.5 & 81.5 & 0.864 \\
\hline Connectedness & 99.7 & 94.7 & $0.006^{* *}$ & 99.7 & 95.3 & $0.004^{* * * *}$ \\
\hline $\begin{array}{l}\text { Social \& } \\
\text { economic } \\
\text { resources }\end{array}$ & 84.4 & 76.2 & $0.026^{* * *}$ & 78.3 & 71.7 & $0.093^{*}$ \\
\hline $\begin{array}{l}\text { Organizational } \\
\text { pattern }\end{array}$ & 88.8 & 81.2 & $0.000^{* * *}$ & 89.8 & 85.5 & $0.036^{* *}$ \\
\hline Clarity & 84.2 & 81.7 & 0.665 & 89.2 & 80.8 & 0.151 \\
\hline $\begin{array}{l}\text { Open emotional } \\
\text { expression }\end{array}$ & 84.6 & 85.9 & 0.735 & 85.8 & 91.6 & 0.100 \\
\hline Problem solving & 84.2 & 93.3 & $0.006^{* * *}$ & 84.3 & 90.0 & 0.162 \\
\hline $\begin{array}{l}\text { Communication } \\
\text { process }\end{array}$ & 86.8 & 85 & 0.137 & 85.8 & 87.4 & 0.285 \\
\hline Total & 85.9 & 84.7 & 0.542 & 87 & 88.5 & 0.459 \\
\hline
\end{tabular}

\section{The Output of Family Resilience}

Mean scores and the T-test results between the output of family resilience at 1 and 4 months post-disaster are presented in Table 6. In general, Garut flash flood victim families experienced financial security problems. T-test results showed no significant difference between the output of family resilience in the temporary and nontemporary shelter at 1 month post-disaster. In contrast, in 4 months post-disaster, families in the temporary shelter had a higher score. This is due to the differences in the ability of the family to 
access social support. The data showed that families in nontemporary shelters experienced a drastic reduction of social support at 4 months post-disaster. However, all the other indicators had improved achievement. This means that although social support decreased, families in nontemporary shelters still have good ability in decision making, problemsolving, adaptation, anticipation, and recovery. All indicators also showed improvement at 4 months post-disaster among families in temporary shelter.

Table 6. Mean scores and the result of t-test between the output of family resilience in 1 and 4 months post-disaster

\begin{tabular}{|c|c|c|c|c|c|c|}
\hline \multirow{2}{*}{$\begin{array}{l}\text { The output of family } \\
\text { resilience }\end{array}$} & \multicolumn{2}{|c|}{1 month } & \multirow{2}{*}{$p$-value } & \multicolumn{2}{|c|}{4 months } & \multirow{2}{*}{$p$-value } \\
\hline & FTS & FTNS & & FTS & FNTS & \\
\hline Decision-making & 77.5 & 76.7 & & 80.0 & 78.6 & \\
\hline Problem solving & 75.2 & 75.5 & & 80.2 & 78.1 & \\
\hline Adaptation & 70.8 & 79.4 & & 78.6 & 81.1 & \\
\hline Financial security & 64.7 & 61.1 & & 65.8 & 63.6 & \\
\hline Social support access & 82.7 & 85.5 & & 84.7 & 40.8 & \\
\hline Anticipation & 76.1 & 70.5 & & 80.0 & 71.9 & \\
\hline Recovery & 73.1 & 74.7 & & 78.6 & 80.2 & \\
\hline Total & 74.3 & 74.8 & 0.872 & 78.3 & 70.6 & $0.012 * *$ \\
\hline
\end{tabular}

\section{Factors that Affect Stress Symptoms}

Tabel 7. The result of multiple linear regression of factors predicting stress symptoms at 1 and 4 months post-disaster

\begin{tabular}{|c|c|c|c|c|c|c|}
\hline \multirow{2}{*}{ Variables } & \multicolumn{3}{|c|}{1 month } & \multicolumn{3}{|c|}{4 months } \\
\hline & $\mathrm{B}$ & Beta & Sig & B & Beta & Sig \\
\hline Constant & 21.782 & & 0.147 & 8.777 & & 0.501 \\
\hline $\begin{array}{l}\text { Residence }(0=\text { temporary shelter; } 1=\text { non temporary } \\
\text { shelter) }\end{array}$ & 4.895 & 0.144 & 0.134 & 3.522 & 0.122 & 0.144 \\
\hline Wife's age (year) & -0.044 & -0.029 & 0.721 & 0.127 & 0.098 & 0.210 \\
\hline Length of husband's education (year) & 0.023 & 0.004 & 0.971 & -0.151 & -0.029 & 0.747 \\
\hline Length of wife's education (year) & -0.807 & -0.110 & 0.238 & 0.572 & 0.092 & 0.319 \\
\hline Family size (person) & -0.237 & -0.023 & 0.775 & -0.325 & -0.037 & 0.633 \\
\hline $\begin{array}{l}\text { Family income/cap/month at } 4 \text { months post-disaster } \\
\text { (IDR thousand) }\end{array}$ & 0.456 & 0.087 & 0.375 & -0.398 & -0.122 & 0.146 \\
\hline Stressors (index) & 0.584 & 0.320 & $0.002^{* * *}$ & 0.251 & 0.185 & $0.063^{*}$ \\
\hline Coping strategies (index) & 0.441 & 0.349 & $0.000^{* * *}$ & -0.263 & -0.228 & $0.010^{* * * *}$ \\
\hline Process of resilience (index) & -0.240 & -0.154 & 0.090 & -0.053 & -0.040 & 0.694 \\
\hline Stress symptoms at 1 month post-disaster & - & - & - & 0.411 & 0.483 & $0.000^{* * *}$ \\
\hline $\mathrm{R}^{2}$ & & 0.378 & & & 0.422 & \\
\hline Adjusted $\mathrm{R}^{2}$ & & 0.327 & & & 0.368 & \\
\hline Sig & & $0.000^{* * *}$ & & & $0.000^{* * * *}$ & \\
\hline $\mathrm{F}$ & & 7.434 & & & 7.942 & \\
\hline
\end{tabular}

The regression model which is developed to analyze factors affecting stress symptoms of Garut flash flood victim families at 1 and 4 months post-disaster, is presented in Table 7 . The results showed factors that partially affected stress symptoms at 1-month 
post-disaster were stressors $(0.584)$, coping strategies $(\mathrm{B}=0.441) \&$ the process of family resilience $(\mathrm{B}=-0.240)$. The higher stressors and coping strategies, the higher the stress symptoms. Whereas the higher process of family resilience, the lower the stress symptoms.

\section{Factors Influenced the Output of Family Resilience}

The regression model developed to analyze factors affecting the output of family resilience at 1 and 4 months post-disaster is presented in Table 8 . The output of family resilience at 1-month post-disaster was affected 22.7 per cent by predictor variables, whereas the output of family resilience at 4 months post-disaster was affected 37.1 per cent by predictor variables. The factor that partially affected the output of family resilience at 1month post-disaster was the process of family resilience $(B=0.626)$. The higher process of family resilience, the higher output of family resilience at 1-month post-disaster.

Tabel 8 The result of multiple linear regression of factors predicting the output of family resilience at 1 and 4 months post-disaster

\begin{tabular}{|c|c|c|c|c|c|c|}
\hline \multirow{2}{*}{ Variables } & \multicolumn{3}{|c|}{1 month } & \multicolumn{3}{|c|}{4 months } \\
\hline & $\mathrm{B}$ & Beta & Sig & $\mathrm{B}$ & Beta & Sig \\
\hline Constant & 9.439 & & 0.538 & 31.277 & & 0.039 \\
\hline $\begin{array}{l}\text { Residence }(0=\text { temporary shelter; } 1=\text { non } \\
\text { temporary shelter })\end{array}$ & 4.645 & 0.143 & 0.164 & -9.428 & -0.283 & $0.001^{* * *}$ \\
\hline Wife's age (year) & 0.116 & 0.080 & 0.361 & -0.026 & -0.017 & 0.825 \\
\hline Length of husband's education (year) & 0.373 & 0.063 & 0.551 & 0.643 & 0.107 & 0.232 \\
\hline Length of wife's education (year) & 0.129 & 0.018 & 0.853 & 0.612 & 0.085 & 0.352 \\
\hline Family size (person) & 0.819 & 0.084 & 0.335 & 0.812 & 0.081 & 0.297 \\
\hline $\begin{array}{l}\text { Family income/cap/month at } 4 \text { months post- } \\
\text { disaster (IDR thousand) }\end{array}$ & 0.864 & 0.173 & 0.102 & -0.877 & 0.233 & $0.005^{* * *}$ \\
\hline Stressors (index) & -0.182 & -0.104 & 0.338 & -0.383 & -0.244 & $0.010^{* *}$ \\
\hline Coping strategies (index) & -0.006 & -0.005 & 0.955 & 0.121 & 0.091 & 0.273 \\
\hline Process of resilience (index) & 0.626 & 0.423 & $0.000^{* * *}$ & 0.363 & 0.239 & $0.020^{* *}$ \\
\hline $\mathrm{R}^{2}$ & & 0.285 & & & 0.419 & \\
\hline Adjusted $\mathrm{R}^{2}$ & & 0.227 & & & 0.371 & \\
\hline Sig & & $.000^{* * * *}$ & & & $0.000^{* * * *}$ & \\
\hline $\mathrm{F}$ & & 4.875 & & & 8.802 & \\
\hline
\end{tabular}

A more detailed regression test was also conducted to analyze the effect of components and subcomponents of predictors variables toward the output of family resilience. Regression tests with a component of main variables as predictors showed organizational pattern (the process of family resilience) had a positive effect on the output of family resilience at 1-month post-disaster. The higher organizational pattern, the higher output of family resilience at 1 month post-disaster. Furthermore, regression tests with subcomponent of main variables as predictors showed positive outlook, as well as social and economic resources $(B=0.161)$, had a positive effect on the output of family resilience at 1-month post-disaster. 


\section{Discussion}

Victim families of Garut flash flood who live in the nontemporary shelter had higher stressors, coping strategies, and stress symptoms rather than those in temporary shelter. This result was supported by Najarian et al. (2017) which found that victims of the earthquake in Armenia who relocated were more protected from psychological problems compared to those who stayed in their former region. Families in the nontemporary shelter, who live in their former residence, tended to feel more anxious, even until the fourthmonth post-disaster, due to the fear of another flash flood that may occur again. Moreover, research by Rathnasinghe, Sirimewan, Shandraseharan, Thurairajah, Thayaparan, and Waidyasekara (2021) found that even the victims who live the emergency shelters and temporary shelter are found to be unsustainable in the long term and may lose their usual life as a family (in terms of social, cultural, environmental or other interactions. We may expect that those who live in the nontemporary shelter may have the worst condition.

In terms of the process of family resilience, family in the temporary shelter had the better meaning of adversity; transcendence and spirituality; connectedness; social and economic resources; and organizational pattern either at 1 or 4 months post-disaster. Based on times, the process of family resilience was higher at 4 months post-disaster compared to 1-month post-disaster in both residences. These findings were supported by Vesely, Letiecq, and Goodman (2017) that family resilience depends on family development and improvement of their resources, structures and cooperation among members. Furthermore, Sunarti, Gunawan, Marliyani, and Ida (2021) found a sharp increase in poverty and a sharp decrease in income in the first month after the disaster.

The more detailed regression analysis showed that family resilience's components that had a significant effect on the output of family resilience were the organizational pattern. Organizational pattern positively affected the output of family resilience at onemonth post-disaster. The family who had better organizational patterns tend to be more resilient. This is in line with Greef and van der Walt (2010), who found that family adaptation during the crisis (having an autistic child) was determined by commitment and flexibility, family hardiness and social support. Those components were also congruent with components of the organizational pattern by Walsh (2003). In addition, research done by Yang, Feldman, Li (2021) found that people from cooperative families can acquire family resilience by frequent cooperation. The organizational pattern consists of three subcomponents: flexibility, connectedness, \& social and economic resources. Among that 3 subcomponents, social and economic resources significantly affect the output of family resilience at one-month post-disaster. These findings are congruent with Greeff and van der Walt (2010); Ismail, Bahari, and Mutang (2017), who found that seeking support from the community enhances family adaptation during crisis time.

Other components of the process of family resilience's are the family belief system and communication process. The family belief system has not significantly affected the output of family resilience. Still, its subcomponent, positive outlook, indicated a consistently positive effect toward the output of family resilience, both at one and four months post-disaster. This is also in line with Greeff, and van der Walt (2010), whose families who have a positive outlook are more active to find problem-solving because of their optimism to bounce back. Furthermore, in terms of individuality, research by 
Panigrahi and Suar (2021) found that among survivors of floods in India, dispositional attributes such as self-efficacy, hope, optimism, striving, and grit contribute to their resilience.

This research also showed that based on the output of family resilience, financial security was the problem of both temporary and nontemporary shelter. Williams, Ntontis, Alfadhli, Drury, and Amlot (2021) argue that problem related financial arrangements impact people's well-being and mental health that are similar to the direct effects of major incidents. The problems exist prior to and impact them during the disaster. Another finding shows that stress symptoms were higher among families in contemporary shelters. The output of family resilience was higher among families in temporary shelters, especially at four months post-disaster.

Further, the regression test showed that type of residence positively affected the output of family resilience at four months post-disaster. This is supported by Najarian et al. (2017), who found that victims who were relocated from disaster-prone areas had a tendency to bounce back more easily than those who remained in the former region. Families living in temporary shelters received more social support even until four months post-disaster, such as free rice and allowance for the student. That social support made families tend to face post-disaster problems easier (Mao and Agyapong, 2021).

At four months post-disaster, in addition to stressors and coping strategies, the regression test showed that stress symptoms were also affected by stress symptoms at onemonth post-disaster positively. The family who experienced higher stressors at one-month post-disaster showed higher stress symptoms at four months post-disaster. This result supports Calvo, Arcaya, Baum, Lowe, and Waters (2015) which found the determinant of post-disaster happiness of Hurricane Katrina victims are exposure to post-disaster stress (in this research was called stressors) and level of mourning and happiness before the disaster (in this research was called stress symptoms at 1-month post-disaster).

Based on McCubbin and Thompson (1997), one of the factors that can help the family to reduce stress symptoms in hard times is family resources. The process of family resilience is part of the intangible family resources, and the regression test result showed that the process of family resilience negatively affected stress symptoms at one-month post-disaster. The family who showed the better quality of the process of family resilience tend to experience fewer stress symptoms at one-month post-disaster. The more detailed analysis showed that the communication process (the process of resilience) negatively affected stress symptoms. The better the communication process among families, the lower the stress symptoms at 1-month post-disaster. Positive communication among family members will help the family to release their anxieties. There is a significant positive relationship between family communication patterns and family resilience (Ramadhana, Karsidi, Utari, Kartono, 2019)

The output of family resilience in both locations was mostly quite good. This is in line with the assumption of resilience by Walsh (2002). They stated that all individuals and families have the opportunity to become resilient, and resilience can be maximized by strengthening the key process of family resilience. The regression test of this research also supports that assumption. The process of family resilience consistently has a significant positive effect toward the output of family resilience, both at one and four months post- 
disaster. Better quality of the process of family resilience leads to the better output of family resilience.

Stressors are one of the predictors of the output of family resilience. The more severe the stressors, the more challenging for the family to become resilient (Patterson, 2002). However, regression test results showed that stressors only significantly affect the output of family resilience at four months post-disaster. It is suspected because, at four-month post-disaster, the family received a lot of aid from the government, volunteers, and community. The number of aids made the overall output of family resilience remain good despite the high stressors. Meanwhile, at four months post-disaster, the aids has decreased and even stopped. It made the significant effect of stressors on the output of resilience becomes more pronounced. Stressors showed a negative effect on the output of family resilience at four months post-disaster. This is in line with Carpena (2015), who found that communication problems (stressors) in families who have children with neurodevelopmental disorders negatively affected family resilience. Families with higher stressors will find it more difficult to solve problems, more difficult to adapt and more difficult to bounce back.

Like stressors, family income per capita does not affect the output of resilience at one-month post-disaster, but it has a positive effect at four months post-disaster. The insignificant effect of family income toward the output of family resilience at one-month post-disaster was also suspected because of the aid received by families. Meanwhile, at the four months post-disaster where the aids have decreased, families started to earn a living by themselves again that making family income become significant toward the output of family resilience. Based on regression test analysis, family income per capita positively affected the output of family resilience at 4 months post-disaster. This is in line with Bonano, Galea, Bucciarelli, and Vlahov (2007), who found that higher-income disaster victims tend to have better resilience. The higher the poverty level, the lower the family resilience (Matos, Leal, Pontes, e Silva, 2021)

The findings of this research emphasize the importance of family resilience to build a resilient family in the face of crises, especially when becoming disaster victims. Therefore, the effort to improve family resilience should strengthen family resilience, and family should become an important part of a disaster risk reduction program. The government should encourage citizens to get involved in risk reduction programs so that citizens do not act only as of the object of the program but also as the subject (Sunarti, Islamia, Fithriyah, Nugraha \& Ulfa, 2017). However, our research still has limitations. First, the measurement of variables only from the perception of wives has not described the complete family condition yet. Second, the design used in this study was cross-sectional and retrospective, but it was used to measure two post-disaster data points. Third, instruments of the output of resilience used in this study were still in the early stages of development. Some indicators still require more detailed measurements. Also, there were several questions in questionnaires of stressors, coping strategies and processes of family resilience that have not been valid according to construct validity but have fulfilled the content validity, so that further development of the instrument is needed. 


\section{Conclusion and Recommendation}

\section{Conclusion}

Based on the results of the study, the resilience process affects the family's ability to recover (output of family resilience), both at 1 and 4 months after the disaster, also affects stress symptoms at one month after the disaster. Furthermore, coping strategies consistently affected stress symptoms at 1 and 4 months post-disaster.

We recommend that it is very important to strengthen the family resilience process as an investment to build family resilience in the face of disasters. Moreover, skills in implementing coping strategies to manage stress need to be improved by every family, especially families of disaster victims.

\section{Recommendation}

As the findings recommend, government, non-governmental organizations (NGOs) and volunteers are expected to include investment in family resilience as part of disaster risk reduction. Furthermore, in the disaster impact and response phase, policymakers and management should not only focus on providing material assistance for disaster victims but also provide programs to strengthen family resilience that will help families become stronger and overcome difficulties. Meanwhile, the next researcher may conduct a resilience study among families of disaster victims by involving more holistic factors, comprehensive methods and advanced analysis.

\section{References}

[BNPB] Badan Nasional Penanggulangan Bencana. (2017). Bencana Indonesia tahun 2016. Retrieved from http://dibi.bnpb.go.id/dibi

[BPBD] Badan Penanggulangan Bencana Daerah Kabupaten Garut. (2016). Rencana aksi pasca banjir bandang Garut. Garut(ID): Indonesia

Benzies, K., \& Mychasiuk, R. (2009). Fostering family resiliency: a review of the key protective factors. Child \& Family Social Work, 14(1), 103-114. Doi: http://dx.doi.org/10.1111/j.1365-2206.2008.00586.x

Bonanno, G.A., Galea, S., Bucciarelli, A., \& Vlahov, D. (2007). What predicts psychological resilience after disaster? The role of demographics, resources, and life stress. Journal of Consulting and Clinical Psychology, 75(2), 671-682. Doi: https://doi.org/10.1037/0022-006X.75.5.671

Calvo, R., Arcaya, M., Baum, C., Lowe, S., \& Waters, M. (2015). Happily ever after? pre and-post-disaster determinants of happiness among survivors of hurricane katrina. Journal of Happines Study, 16, 427-442. Doi: 10.1007/s10902-014-9516-5

Carpena, G.L. (2015). Predictors of family resilience in families of children with autism spectrum disorder. [Thesis]. Department of Counselling in psychology, Adler University, Chicago, USA.

Glandon, D. M., Muller, J., \& Almedom, A. M. (2008). Resilience in post-katrina New Orleans, Louisiana: a preliminary study. African Health Sciences, 8(1), 21-28. PMC3060720 
Greeff, A.P., \& van der Walt, K. J. (2010). Resilience in Families with an Autistic Child. Education and Training in Autism and Developmental Disabilities, 45(3), 347-355.

Ismail, R., Bahari, F., \& Mutang, J. A. (2017). Strengthening family and community resilience in traumatic flood disasters: intervention guidelines and model program. Asia Pacific Institute of Advanced Research (APIAR), 3(2), 148-157. Doi: 10.25275/apjabssv3i2bus13

Lazarus, R. S, \& Folkman, S. (1985). If it changes it must be a process: study of emotion and coping during three stages of a college examination. Journal of Personality and Social Psychology, 48(1), 150-170. Doi: 10.1037//0022-3514.48.1.150

MacPhee, D., Lunkenheimer, E., \& Riggs, N. (2015). Resilience as regulation of developmental and family processes. Fam Relat, 64(1), 153-175. Doi: $10.1111 /$ fare. 12100 .

Mao, W., \& Agyapong, V. (2021). The Role of Social Determinants in Mental Health and Resilience After Disasters: Implications for Public Health Policy and Practice. Frontiers in public health, 9, 658528. https://doi.org/10.3389/fpubh.2021.658528

Maryam, S., Sukandar, D., Guhardja, S. S., Asngari, P., \& Sunarti, E. (2008). Analisis faktor-faktor yang mempengaruhi keberfungsian pasca gempa dan tsunami di Nanggroe Aceh Darussalam. Media Gizi \& Keluarga, 52, 40-51.

Matos, L.A., Leal, E.M.R., Pontes, F.A.R. et al. Poverty and family resilience in BelémPará. Psicol. Refl. Crít.34, 12 (2021). https://doi.org/10.1186/s41155-021-00176-X

McCubbin, I. H., \& Thompson, A. I (1997). Family Assessment Inventories for Research and Practice. Wiconsin(UK): University of Wisconsin-Madison

McCubbin, M. A., \& Patterson. (1981). Family Stress Theory and Assessment. Wiconsin(UK): University of Wisconsin-Madison

McDermott, B., \& Cobham, V. (2012). Family functioning in the aftermath of a natural disaster. BMC Psychiatry, 12(55), 1-7. Doi: 10.1186/1471-244X-12-55

Mirowski, J., \& Cathrine, E. R. (2002). Measurement for a human science. Journal of Health and Social Behavior, 43, 152-170.

Najarian, L. M., Majeed, M. H., \& Gasparyan, K. (2017) Effect of relocation after a natural disaster in Armenia : 20 year follow up. Asian Journal of Psychiatry, 29, 8-12. Doi: https://doi.org/10.1016/j.ajp.2017.03.030

Oh, S., \& Chang, S. J. (2014). Concept analysis: family resilience. Open Journal of Nursing, 4, 980-990. Doi: http://dx.doi.org/10.4236/ojn.2014.413105

Panigrahi, G. S., \& Suar, D. (2021). Resilience among survivors in the aftermath of the 2018 Kerala flood: An avenue toward recovery. International Journal of Disaster Risk Reduction, 64, 102477. doi:10.1016/j.ijdrr.2021.102477

Patterson, J. (2002). Integrating family resilience and family stress theory. Journal of Mariage and Family,64(2), 349-360. Doi: https://psycnet.apa.org/doi/10.1111/j.17413737.2002.00349.x

Ramadhana, M. R., Karsidi, R., Utari, P., \& Kartono, D. T. (2019). Role of Family Communications in Adolescent Personal and Social Identity. Journal of Family Sciences, 4(1), 1-11. https://doi.org/10.29244/jfs.4.1.1-11

Rathnasinghe, A., Sirimewan, D., Shandraseharan, A., Thurairajah, N., Thayaparan, M. and Waidyasekara, K.G.A.S., (2021). Towards long-term sustainable performance of post-disaster housing reconstruction: Second life for temporary housing. In: 
Sandanayake, Y.G., Gunatilake, S. and Waidyasekara, K.G.A.S. (eds). Proceedings of the 9 th World Construction Symposium, 9-10 July 2021, Sri Lanka. [Online]. pp. 540 -552. https://doi.org/10.31705/WCS.2021.47. Available from: https://ciobwcs.com/papers/

Rubbyana, U. (2012). Hubungan antara strategi koping dengan kualitas hidup pada penderita skizofrenia remisi symptom. Jurnal Psikologi Klinis dan Kesehatan Mental, 1(2), 59-66. ISSN: 2301-7082.

Sunarti, E. (2007). Theoritical and methodological issues on family resilience. Presented at Senior Official Forum on Families, Nusa Dua Bali, September, 2007.

Sunarti, E. (2015). Ketahanan Keluarga Indonesia: dari Kebijakan dan Penelitian Menuju Tindakan, Institut Pertanian Bogor

Sunarti, E., \& Syahrini, J. (2011). Pengelolaan stres pada keluarga korban longsor di Kabupaten Garut. Jurnal Ilmu. Keluarga. \& Konsumen, 4, 111-120. Doi: https://doi.org/10.24156/jikk.2011.4.2.111

Sunarti, E., Gunawan, E., Widiyantoro, S., Marliyani, G. I., \& Ida, R. (2021). Critical point on housing construction, resilience and family subjective welfare after disaster: Notes from the Lombok, Indonesia, earthquake sequence of July-August 2018. Geomatics, Natural Hazards and Risk, 12(1), 922-938. doi:10.1080/19475705.2021.1910

Sunarti, E., Ifada, Q., Desmarita, O., \& Hasanah, S. (2005). Ketahanan keluarga, manajemen stress, dan pemenuhan fungsi ekonomi dan fungsi sosialisasi. Jurnal Ilmu Keluarga dan Konsumen, 4, 111-120.

Sunarti, E., Islamia, I., Faizah, A., Nugraha, D. R., \& Ulfa. M. (2017). Keilmuan sosial ekonomi untuk pengurangan risiko bencana dalam kaitannya dengan pencapaian tujuan pembangunan berkelanjutan (kasus banjir di Baleendah, Kab. Bandung). Jurnal Riset Kebencanaan Indonesia,3, 9-16. ISSN: 2443-2733.

Sunarti, E., Praptiwi, R., \& Muflikhati, I. (2011). Kelentingan keluarga, dukungan sosial, dan kesejahteraan keluarga nelayan juragan dan buruh di daerah rawan bencana. Jurnal Ilmu Keluarga \& Konsumen, 4(1), 1-10. Doi: https://doi.org/10.24156/jikk.2011.4.1.1

Vesely, C. K., Letiecq, B. L., \& Goodman, R. D. (2017). Immigrant Family Resilience in Context: Using a Community-Based Approach to Build a New Conceptual Model. Journal of Family Theory \& Review, 9(1), 93-110. doi:10.1111/jftr.12177

Walsh, F. (2002). A family resilience framework: innovative practice applications. Family Relations, 51(20), 130-138. Doi: 10.1111/j.1741-3729.2002.00130.x

Walsh, F. (2003). Family resilience : a framework for clinical practices. Family Process, 42(1), 1-18.

Walsh, F. (2007). Traumatic loss and major disasters: strengthening family and community resilience. Family Process, 46(2), 207-227. Doi: 10.1111/j.1545-5300.2007.00205.x.

Yang, B., Feldman, M.W. \& Li, S. The Status of Family Resilience: Effects of Sustainable Livelihoods in Rural China. Soc Indic Res153, 1041-1064 (2021). https://doi.org/10.1007/s11205-020-02518-1 